\title{
Impairment of the cell-to-matrix adhesion and cytotoxicity induced by the Mediterranean jellyfish Pelagia noctiluca venom and its fractions in cultured glioblastoma cells
}

\author{
Yosra Ayed ${ }^{1}$, Manel Bousabbeh¹, Hazem Ben Mabrouk², Maram Morjen², Naziha Marrakchi ${ }^{2}$ and Hassen Bacha ${ }^{1,3,4^{*}}$
}

\begin{abstract}
Background: The biodiversity of the marine environment and the associated chemical diversity constitute a practically unlimited source of new active substances in the field of the development of bioactive products. In our study, we have investigated the efficiency of the venom from the Mediterranean jellyfish, Pelagia noctiluca and its fractions for anti-proliferative and anti-cell adhesion to cell-extracellular matrix activities.

Results: Our experiments have indicated that the separation of the Mediterranean jellyfish Pelagia noctiluca crude venom extract by sephadex G-75 chromatography led to four fractions (F1, F2, F3, and F4). Among the four fractions F1 and F3 were cytotoxic against U87 cells with IC50 values of 125 and $179 \mu \mathrm{g} / \mathrm{ml}$ respectively. The venom, F1, F2 and F 3 showed significant anti-proliferative activity in time-dependent manner. Our results also suggest that these fractions and the venom are able to inhibit cell adhesion to fibrinogen in dose-dependent manner. This inhibition is reliant on its ability to interact with integrins.

Conclusions: To conclude, we have demonstrated for the first time that Pelagia noctiluca venom and its fractions especially (F1 and F2) display potent anti-tumoral properties. Separation by sephadex G-75 chromatography give rise to more active fractions than the crude venom extract. The purification and the determination of chemical structures of compounds of these active fractions are under investigation. Overall, Pelagia noctiluca venom may has the potential to serve as a template for future anticancer-drug development.
\end{abstract}

Keywords: Pelagia noctiluca, Venom, Sephadex G-75, Cell proliferation, Cell adhesion

\section{Background}

Gliomas are the most common form of brain tumour [1]. Malignant gliomas are highly invasive, and as such, are neurologically destructive. Survival rates are poor because present therapies, including surgery, radiation therapy and chemotherapy, have limited effectiveness [2]. Finding new therapeutic strategies targeting multiple cell signaling pathways, such as inhibition of proliferation, adhesion, migration and angiogenesis, have been a

\footnotetext{
* Correspondence: hassen-bacha@fmdm.rnu.tn

'Laboratory for Research on Biologically Compatible Compounds, Faculty of Dentistry, Rue Avicenne, Monastir 5019, Tunisia

${ }^{3}$ University of Jendouba, Cité AlFaeiz rue Jamil Boutheina, Jendouba 8100, Tunisia

Full list of author information is available at the end of the article
}

major point of concern for research in the pharmaceutical sciences.

Extensive research has shown that cell-adhesion activities are deregulated in many diseases such as cancer. Therefore, the characterization of molecules capable to inhibit these alterations is considered very important for the development of alternative therapies [3]. Snake venoms are complex mixtures of molecules possessing various biological functions. Researches have been shown that several snake venom-derived peptides can affect cell adhesion, proliferation and angiogenesis by interacting with integrins $[3,4]$.

Recently, the marine environment has been recognized as a rich source of bioactive metabolites with varied biological and pharmacological activities [5-11]. Some 
anticancer agents were derived from the venoms of cnidarians. The most studied cnidarian compounds are the secondary metabolites from soft corals such as diterpenes, sesquiterpenes, terpenoids, and monoterpenoids [12]. The jellyfish Pelagia noctiluca (P. noctiluca) [13], (class Scyphozoa, order Semaestomeae, family Pelagiidae), is widely distributed in different parts of the Mediterranean Sea [14-16] and in the Atlantic Ocean [17]. Therefore, it is the most dangerous autochthonous Mediterranean jellyfish [16], able to reconstitute its stinging battery within few days after discharge [18]. Nematocysts (or cnidocysts) are characteristically used by jellyfish to defend themselves against predator and to capture prey. These organelles contain irritating poisons, and are armed with sharp hollow threads that deliver venom causing painful stings. Nematocysts are located along the tentacles and body. Proteins isolated from jellyfish, with a unique structure, have many bioactivities such as enzymatic activities, hemolysin, dermonecrotic factor, and cytolysin [16-19]. However, little is known about the anti-tumor activity of the active components of $P$. noctiluca venom and their mechanism of action on cancer cells remains unknown.

Thus, this study attempts, for the first time to characterize and evaluate the exact role of $P$. noctiluca venom and its semi-purified fractions on (i) viability of human glioblastoma cells (U87), (ii) cell proliferation and (iii) cell adhesion to immobilized extracellular matrix (ECM) protein (fibrinogen).

\section{Materials and methods Chemicals}

3-4, 5-dimethylthiazol-2-yl, 2,5-diphenyltetrazolium bromide (MTT), Cell culture medium (RPMI1640), foetal calf serum (FCS), phosphate buffer saline (PBS), trypsin-EDTA, penicillin and streptomycin mixture and l-glutamine (200 mM) were from GIBCO-BCL (UK). Poly-L-lysine, Human fibrinogen was purchased from Sigma (St Quentin Fallavier, France). All other chemicals used were of analytical grade.

\section{Preparation of nematocysts}

Specimens of $P$. noctiluca were collected from the bay of Monastir, Tunisia, in May 2011, and identified by professor Mohamed Nejib Daly Yahia from Faculty of Sciences of Bizerte, (Bizerte, Tunisia). Tentacles were excised manually from living specimens immediately after capture.

The nematocysts isolation method has been previously described by Arillo et al. [20] with a slight modification. Tentacles were submerged in distilled water for $5 \mathrm{~h}$ at $4^{\circ} \mathrm{C}$. The ratio of organic tissue to distilled water was approximately 1:5 (v/v). After a complete detachment of the epidermis, the tissue was removed from the suspension containing both epidermis and undischarged nematocysts deriving from the osmotic rupture of nematocysts. The nematocysts, attached to the epidermal tissue, were separated by stirring. The nematocysts suspension was repeatedly washed in distilled water and filtered through plankton nets to remove most of the tissue debris, and then centrifuged at $4^{\circ} \mathrm{C}$ (ALC PK 120R, $4000 \mathrm{~g}$ for $5 \mathrm{~min}$ ). The content, purity and integrity of nematocysts (cnidocysts) were controlled microscopically [21].

\section{Nematocysts lysis and protein extraction}

Crude venom was extracted by sonication on ice (Sonoplus, $70 \mathrm{mHz}, 30$ times, $20 \mathrm{~s}$ ) of nematocysts as described by Marino et al. [21]. After sonication, the suspension was centrifuged at $15,000 \mathrm{rpm}$ for $15 \mathrm{~min}$ at $4^{\circ} \mathrm{C}$. The supernatant was carefully removed, filtered and lyophilized.

\section{Protein determination}

The protein content of $P$. noctiluca venom was determined according to the Bradford method (BioRad Labs, Hercules, CA) [22]. "venom and fractions concentrations" refer to protein concentration expressed in units of $\mu \mathrm{g} \mathrm{ml} l^{-1}$.

\section{Size exclusion chromatography}

About $300 \mathrm{mg}$ of crude venom of $P$. noctiluca was dissolved in filtered-degassed double-distilled water. After centrifugation at $17000 \mathrm{~g}$ for $15 \mathrm{~min}$ at $4^{\circ} \mathrm{C}$, the supernatant was loaded on Sephadex G-75 gel-filtration chromatography columns $(2.6 \times 100 \mathrm{~cm}$; Pharmacia), previously equilibrated with $200 \mathrm{mM}$ ammonium acetate, $\mathrm{pH}$ 6.8 and eluted under the same conditions. The flow rate was $3 \mathrm{ml} / \mathrm{min}$ using a Bio-Rad 2110 fraction collector and the elution of the proteins was monitored at $280 \mathrm{~nm}$ by an ultraviolet detector.

\section{Cell viability assay}

Cytotoxicity of $P$. noctiluca crude venom and its fractions was defined using the colorimetric method described by Mossmann, [16]. The MTT test assesses cell metabolism based on the ability of the mitochondrial succinate-dehydrogenase to convert the yellow compound MTT to a blue formazan dye. The amount of dye produced is proportional to the number of live metabolically active cells.

Cells were seeded on 96-well culture plates (Polylabo, France) at $10^{5}$ cells/ well and treated with increasing concentrations of crude venom extract at $37^{\circ} \mathrm{C}$. After $24 \mathrm{~h}$, the culture medium was replaced by $200 \mu \mathrm{l}$ medium containing $0.5 \mathrm{mg} / \mathrm{ml} \mathrm{MTT}$ and the plates were incubated 3 hours at $37^{\circ} \mathrm{C}$. The medium was then removed and replaced by $200 \mu \mathrm{l}$ of $(0,04 \mathrm{M} \mathrm{HCl} /$ isopropanol $)$ to solubilize the converted purple dye in culture plates. The 
absorbance was measured on a spectrophotometer microplate reader (Dynatech 4000) at $560 \mathrm{~nm}$.

Cell viability was expressed as the relative formazan formation in treated samples as compared to control cells (untreated cells) [(A560 treated cells/A560 control cells) 100\%]. IC50 values are defined as the concentration that induces $50 \%$ loss of cell viability.

For morphological analysis, U87 cells were treated with 50 and $100 \mu \mathrm{g} / \mathrm{ml}$ of $P$. noctiluca crude venom or F1 or F2 or F3 or F4. Morphological changes were examined and recorded under an inverted phase contrast microscope (Olympus IX50 with a PMC35Dx photo micrograph system). Each experiment was performed in triplicates.

\section{Cell proliferation assay}

U87 cells were plated $\left(3 \times 10^{3} /\right.$ well $)$ in 96 -well plates (Nunc, Denmark) in their complete medium and were incubated for $24 \mathrm{~h}$ before addition of $P$. noctiluca venom and its fractions. After the incubation, the normal medium was replaced for an extract containing medium at the concentrations of $10 \mu \mathrm{g} / \mathrm{ml}$ and treated for 48, 72, 96, and $120 \mathrm{~h}$. The control cells were maintained in normal medium.

The effect of tested compounds on proliferation of U87 cell line was determined using the MTT assay (previously described). Absorbance of the colored solution was measured on a microplate photometer (Dynatech 4000) using a wavelength of $560 \mathrm{~nm}$. The anti-proliferative effect of the tested extracts was determined by comparing the optical density of the treated cells against the optical density of the control (untreated cells).

\section{Cell adhesion assay}

The human glioblastoma (U87) cell line was routinely cultured in RPMI (GIBCO) medium with 10\% FCS. Adhesion assay was performed as previously described [23]. Briefly, flat bottom 96-well microtiter plates were coated with one of the following purified ECM proteins: $50 \mu \mathrm{g} / \mathrm{ml}$ fibrinogen (Fg) or poly-L-lysine (Poly-L) and were blocked with BSA. Cells were harvested in single cell suspension and resuspended in RPMI containing 0.2\% BSA (adhesion buffer) in the presence or absence of $P$. noctiluca crude venom and its fractions. After incubation for $30 \mathrm{~min}$ at room temperature, cells were added to coated wells in a volume of $50 \mu \mathrm{l}\left(10^{6} \mathrm{cells} / \mathrm{ml}\right)$ and allowed to adhere with the substrate for $1 \mathrm{~h}$ at $37^{\circ} \mathrm{C}$ in order to activate alpha $\mathrm{v}$ beta 3 integrin. Unattached cells were removed by gently washing three times with adhesion buffer. Residual attached cells were fixed by $1 \%$ glutaraldehyde, stained by $0.1 \%$ crystal violet and lysed with $1 \%$ SDS. Absorbance was then measured at $600 \mathrm{~nm}$ by a microplate reader.

\section{Statistical analysis}

All data are expressed as means \pm standard error of the mean (SEM) of at least 3 independent experiments. Statistical differences were evaluated by 1-way ANOVA followed by Tukey's test using commercially available software (SPSS 17.0; SPSS Inc., Chicago, Ill.). P values $<0.05$ were considered statistically significant.

\section{Results}

\section{Sephadex G-75 chromatography}

Separation of crude venom of $P$. noctiluca was achieved by a size exclusion chromatography (sephadex G 75). This gel is a dextran capable of separating proteins with molecular weights between 3 and $70 \mathrm{KDa}$. Proteins with

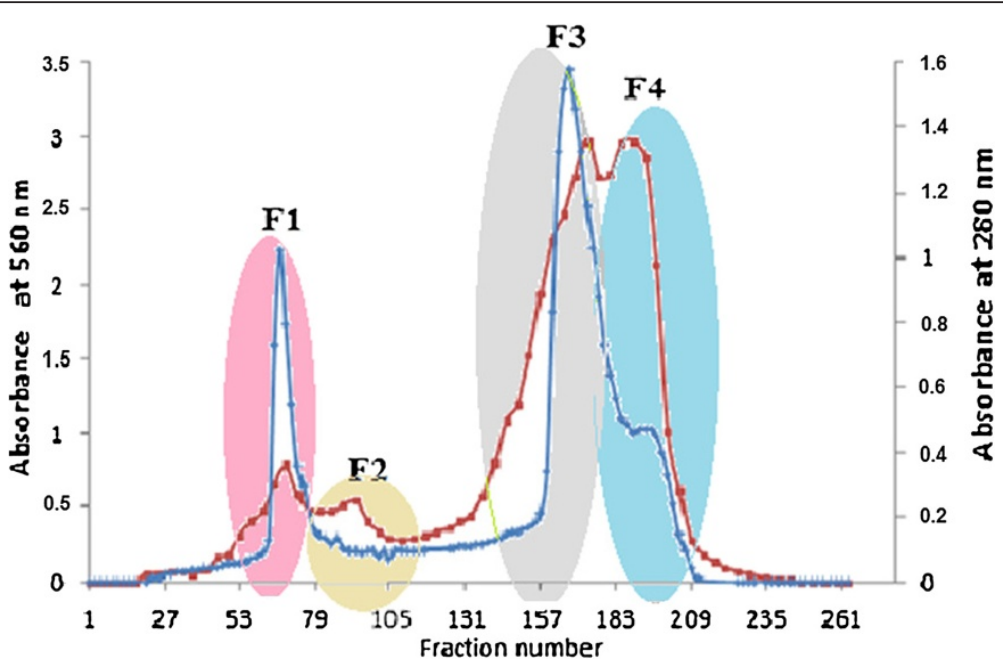

Figure $1 \mathrm{Gel}$ filtration chromatography of $P$. noctiluca crude venom on a Sephadex $\mathrm{G} 75$ column. Elution was performed at $18 \mathrm{ml} / \mathrm{h}$ and $3 \mathrm{ml}$ aliquots were collected. Four fractions and two major peaks were obtained. 
molecular weights greater than $70 \mathrm{KDa}$ are completely excluded.

The crude $P$. noctiluca venom $(300 \mathrm{mg}$ ) was loaded on a previously equilibrated Sephadex G-75 column $(2.6 \times 100 \mathrm{~cm}$; Pharmacia) after washing the column with $900 \mathrm{ml}$ of $200 \mathrm{mM}$ ammonium acetate buffer, $\mathrm{pH} 6.8$. The venom components were eluted with the same buffer at a flow rate of $18 \mathrm{ml} / \mathrm{h}$. Fractions were collected. Protein elution was monitored at $280 \mathrm{~nm}$ and protein contents were determined using the Bradford Method [22]. The fractions obtained were grouped into four groups and were pooled, lyophilized and evaluated in U87 cell line (Figure 1).

\section{Inhibition of cell viability}

The effect of crude venom of $P$. noctiluca and its fractions (from the gel filtration chromatography) on cells viability was assessed by the MTT assay [24]. Cultured cells were exposed to increasing concentrations of crude venom of P. noctiluca and its fractions for $24 \mathrm{~h}$. As shown in Figure 1, all concentrations of crude venom (from 50 to $400 \mu \mathrm{g} / \mathrm{ml}$ ) were sufficient to inhibit viability of U87 cells, with a dose-dependent characteristic (Figure 2). IC50 value was about $180 \mu \mathrm{g} / \mathrm{ml}$ (Table 1). However, we observed that all semi-purified fractions act differently on cell viability. Reduction in the viability of U87 cells by F1 has been already significant at low concentrations and the estimated IC50 was about $125 \mu \mathrm{g} / \mathrm{ml}$. It indicates that F1 is more potent than the crude venom extract. A decrease of cell viability was also observed when cells were treated with F3, IC50 value was around $179 \mu \mathrm{g} / \mathrm{ml}$ (Table 1). F2 and F4 had no cytotoxic effect on U87 cells.

The morphological and growth characteristics were assessed by observation of the cultures using an inverted phase contrast microscope. Cells treated with crude
Table 1 IC50 values of of $P$. noctiluca venom and its fractions (F1- F4) on U87 cell line as determined by cell viability and cell adhesion assays

\begin{tabular}{cccc}
\hline & Cell Viability & Cell Proliferation & Cell Adhesion \\
\hline & $I C_{50}(\mu \mathrm{g} / \mathrm{ml})$ & ++ & $\mid \mathrm{C}_{50}(\mu \mathrm{g} / \mathrm{ml})$ \\
Venom & 180 & +++ & 25 \\
F1 & 125 & +++ & 5 \\
F2 & - & + & 64 \\
F3 & 179 & - & 100 \\
F4 & - & - & - \\
\hline
\end{tabular}

Effects of $P$. noctiluca venom and its fractions (F1- F4) on cell proliferation, $(-)$ no effect, $(+)$ low, $(++)$ medium, $(+++)$ important.

venom, F1 and F3 exhibited changes in their morphology (Figure $3(\$)$ ). During this incubation, a number of cells was also detached from the culture flasks and died.

\section{Inhibition of cell proliferation}

U87 cells were grown in 96-well assay plates and their proliferation was measured over 5 days in four separate independent experimental trials to determine if the administration of $P$. noctiluca venom and its fractions at $10 \mu \mathrm{g} / \mathrm{ml}$ were sufficient to inhibit cellular proliferation. Cells did not receive fresh medium during these periods of incubation.

Our results demonstrated that comparison of treated cells to untreated control cells at day 2 to day 5 revealed that the venom, F1 and F2 had significant effect on cell proliferation when applied at $10 \mu \mathrm{g} / \mathrm{ml}(\mathrm{P}<0.05$, Figure 1). $120 \mathrm{~h}$ of incubation with venom or its fractions were employed for U87 to demonstrate the extreme cytotoxic effect of $P$. noctiluca venom and its fractions on these cells. Despite the long period of incubation $(120 \mathrm{~h})$ without adding fresh medium, untreated U87

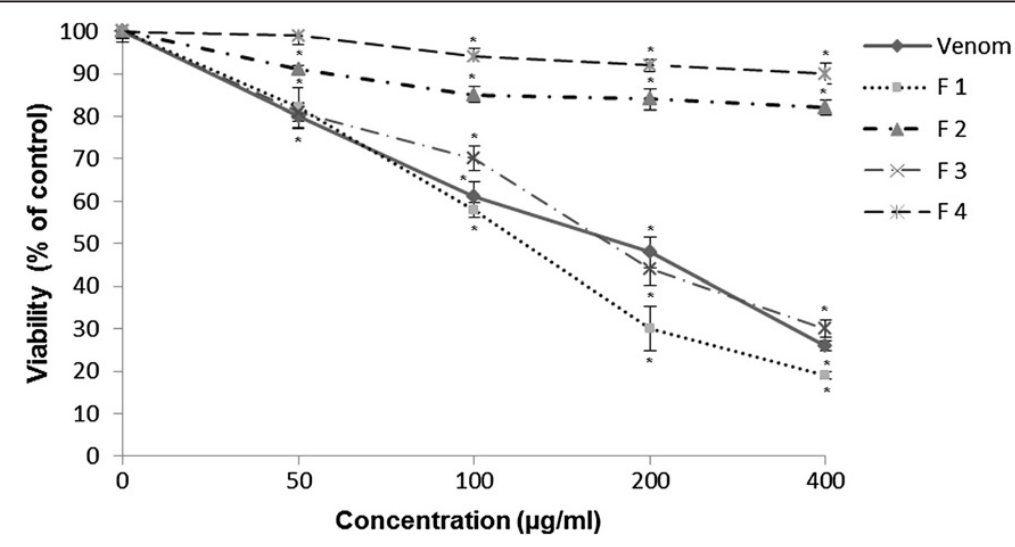

Figure 2 Cytotoxic effect of $P$. noctiluca crude venom and fractions (F1 -F4) on U87 cells. Cells were treated with venom and its fractions at the indicated concentrations for $24 \mathrm{~h}$. Cell viability was determined using the MTT assay and expressed as percentages of control which was exposed to vehicle only. Control value was taken as $100 \%$. Data are expressed as the mean \pm S.E. ${ }^{*} p<0.05$ compared with control (untreated cells). 


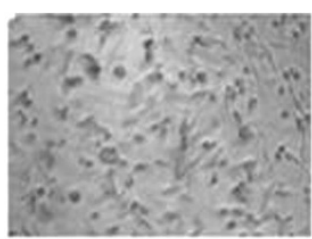

Control

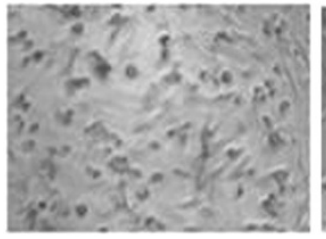

Control

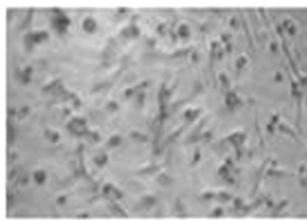

Control

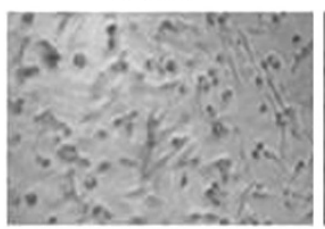

Control

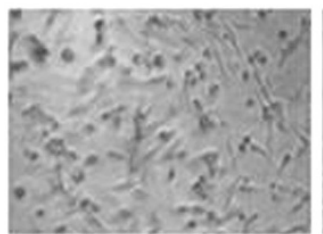

Control

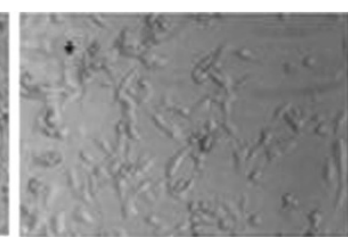

$V(50 \mu \mathrm{g} / \mathrm{ml})$

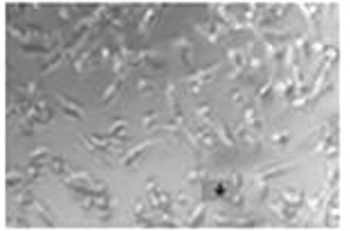

$\mathrm{F} 1(50 \mathrm{\mu g} / \mathrm{ml})$

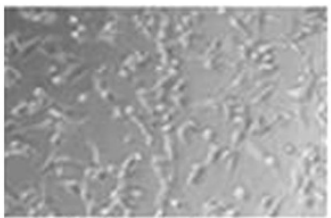

F2 $(50 \mu \mathrm{g} / \mathrm{ml})$

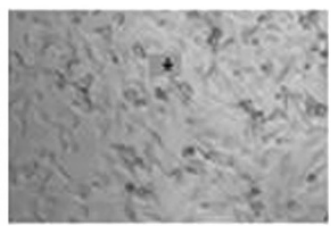

$\mathrm{F} 3(50 \mu \mathrm{g} / \mathrm{ml})$

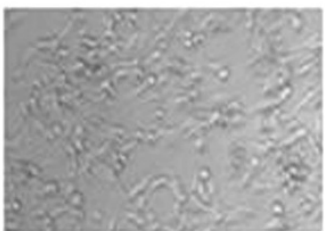

$\mathrm{F} 4(50 \mu \mathrm{g} / \mathrm{ml})$

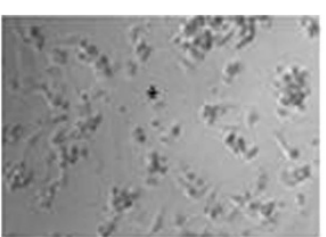

$\mathrm{V}(100 \mu \mathrm{g} / \mathrm{ml})$

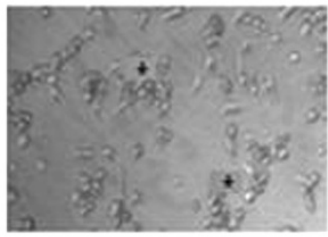

$\mathrm{F} 1(100 \mu \mathrm{g} / \mathrm{ml})$

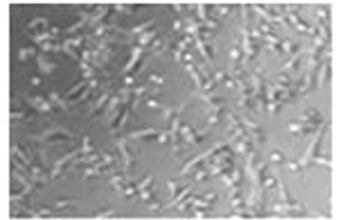

F2 $(100 \mu \mathrm{g} / \mathrm{ml})$

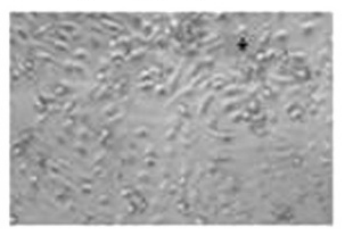

F3 $(100 \mu \mathrm{g} / \mathrm{ml})$

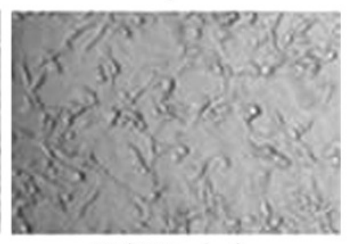

$\mathrm{F} 4(100 \mu \mathrm{g} / \mathrm{ml})$

Figure 3 Effects of 50 and $100 \mu \mathrm{g} / \mathrm{ml}$ of $P$. noctiluca venom or its fractions (F1-F4) on U87 cell morphology in vitro. This figure demonstrates that venom, F1 and F3 reduced cell growth when compared with untreated cells. Some cells displayed altered morphology (am). Cells were observed with phase contrast microscope (original magnification $\times 100$ ).

cells survived as well as those cells from a shorter period of incubation.

As shown in Figure 4, F3 treatments slightly inhibited glioma cells growth (of about $15 \% \pm 1.02$ ). F4 had no effect since F4-treated cells were comparable to untreated cells, whereas venom, F1 and F2 were more effective. In particular, $P$. noctiluca venom at the same concentration used for all tested compounds $(10 \mu \mathrm{g} / \mathrm{ml})$ induced a $64 \% \pm 1.06$ reduction of cell growth rate after $120 \mathrm{~h}$. F2 caused a consistent growth inhibition of about $45 \% \pm 1.6$, whereas the analysis of relative change in proliferation between the control and F1 revealed that it caused the largest reduction of cell survival, approximately $80 \% \pm 2.5$. This decrease in cell survival was statistically significant compared with the untreated control (p $<0.05$ ) (Figure 4). Treatment with F1 showed an inhibitory effect on cell proliferation similar to the Treatment of cells with $5 \mu \mathrm{M}$ Cisplatinum, a chemotherapeutic drug known as potent cytotoxic agent on cancer cell lines, used as a positive control. On the basis of these results we decided to further investigate on the anti-tumor activity of the venom and its active fractions.

\section{Inhibition of cell adhesion}

In a first set of experiments, we have assessed whether $P$. noctiluca venom or its fractions exert an inhibitory effect on adhesion of U87 cells to purified ECM protein used as substratum. Our results clearly showed that the venom at a concentration of $50 \mu \mathrm{g} / \mathrm{ml}$ inhibited attachment of the glioblastoma cell line to fibrinogen, U87 cell adhesion to fibrinogen was also affected by F1, F2 and F3 at a concentration of 50, 100 and $50 \mu \mathrm{g} / \mathrm{ml}$ 


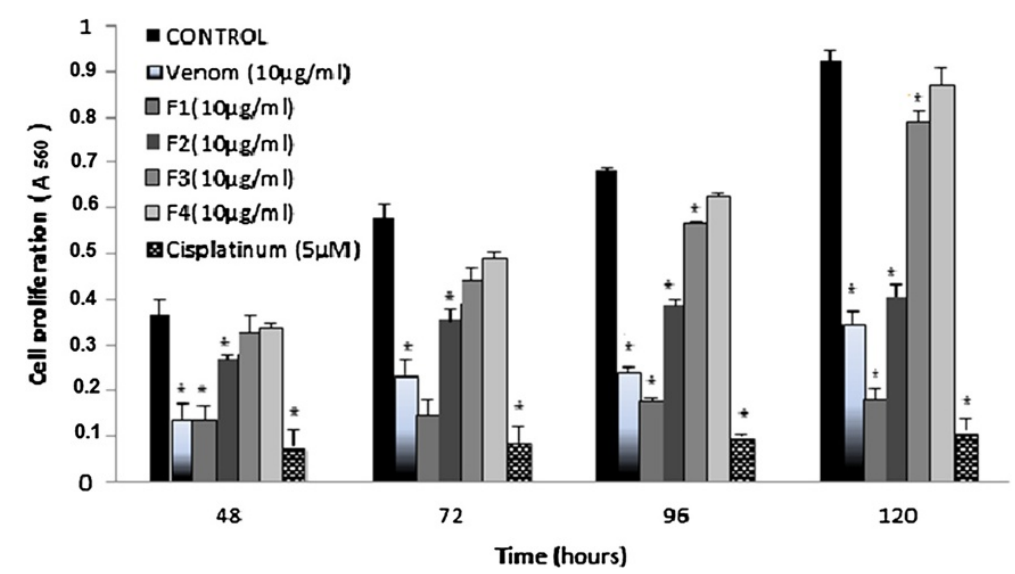

Figure 4 P. noctiluca venom or its fractions (F1-F4) inhibit tumour cells proliferation. U87 cells were cultured for the indicated periods of time in the absence or in the presence of $10 \mu \mathrm{g} / \mathrm{ml}$ of venom or its fractions (F1-F4). Cell proliferation activity was evaluated by using MTT assay. Measurement of the absorbance was performed at a wavelength of $560 \mathrm{~nm}$. The results are from a representative experiment of two performed in triplicate. ${ }^{*} p<0.05$ compared with control (untreated cells).

respectively (concentrations corresponding to IC10). No effect could be observed on the integrin independent substratum, poly-L-lysine, suggesting that the effect of the tested compounds indeed involved the integrin family of adhesion receptors. At a concentration of $100 \mu \mathrm{g} /$ ml, F4 had no effect on the adhesion of U87 cells neither to fibrinogen nor to poly-L-lysine (Figure 5).

In a second set of experiments, we measured the effect of various concentrations of $P$. noctiluca venom or its fractions (F1-F4) against U87 cell adhesion to fibrinogen (Fg). As shown in Figure 6, the venom, F1, F2 and F3 inhibited the adhesion of U87 cells to fibrinogen. This inhibition was dose-dependent, with an IC50 values of 5, 64 and $100 \mu \mathrm{g} / \mathrm{ml}$ respectively. We found that F4 did not significantly affect U87 cells. According to this test, the inhibitory effect of U87 cell adhesion to fibrinogen ranking was $\mathrm{F} 1>$ venom $>$ F2 $>$ F3.

\section{Discussion}

As the toxicity of cnidarian venoms is a well-known subject [25], the aim of this paper is to demonstrate for the first time that the venom of the jellyfish $P$. noctiluca, can also exert anti-tumour activity in vitro.

Analysis of $P$. noctiluca venom on SDS-PAGE revealed at least 15 protein bands ranging in molecular weights from 4 to $120 \mathrm{kDa}$ [26]. Sephadex G75 chromatography led to the separation of the venom on four major fractions.

The mechanisms of venom-induced cytotoxicity are particularly interesting mainly for defining the concentration range for further in vitro testing [27]. For this purpose we have demonstrated that a decrease in cell viability is moderately induced in U87 cells exposed to crude venom extract of $P$. noctiluca in a dose-dependent manner with an IC50 about $180 \mu \mathrm{g} / \mathrm{ml}$ (Figure 2,

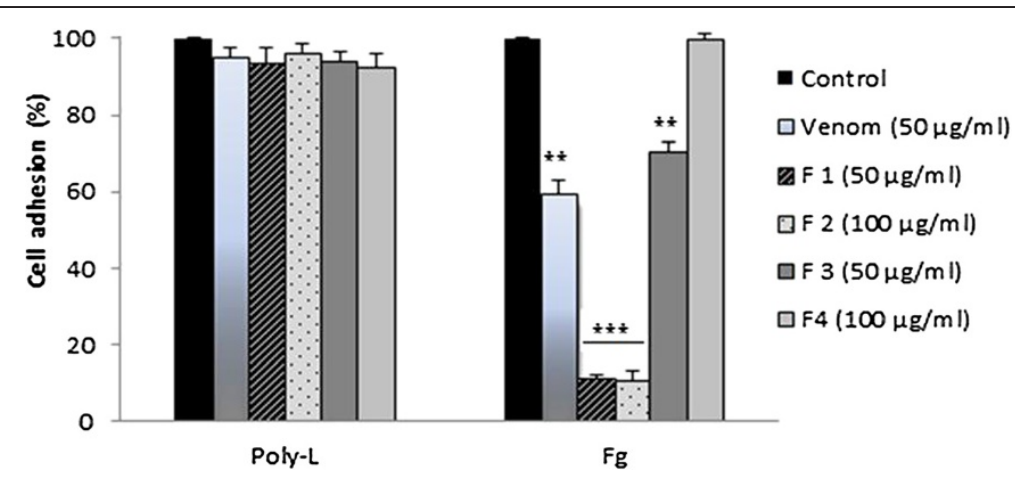

Figure 5 U87 cells were preincubated without (control) or with 50, 50, 100, 50 and $100 \mu \mathrm{g} / \mathrm{ml}$ of venom, F1, F2, F3 and F4 respectively for $\mathbf{3 0 ~} \mathrm{min}$ at room temperature. Cells were then added to $96-$ well microtiter plates coated with $10 \mathrm{mg} / \mathrm{ml}$ with $50 \mathrm{mg} / \mathrm{ml}$ fibrinogen (Fg) or poly-L-lysine (Poly-L) and allowed to adhere for $1 \mathrm{~h}$ at $37^{\circ} \mathrm{C}$. After washing, adherent cells were fixed, stained with crystal violet, solubilized by SDS and the absorbance was measured at $600 \mathrm{~nm} .{ }^{* *} \mathrm{p}<0.01,{ }^{* *} \mathrm{p}<0.001$ compared with control (untreated cells). 


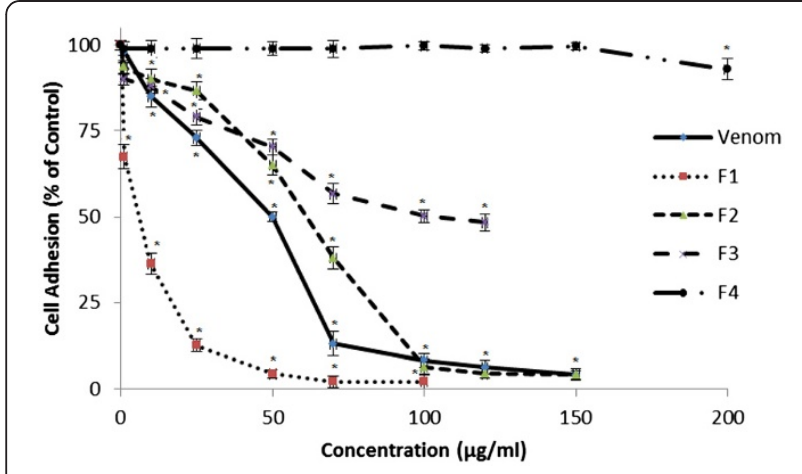

Figure 6 Dose-effect of $P$. noctiluca venom and its fractions (F1F4) on U87 cell adhesion to fibrinogen. $N=4$ (at least). Cell adhesion towards fibrinogen was performed in the presence of the indicated concentrations of $P$. noctiluca venom and its fractions (F1F4). Data shown

$( \pm S D)$ are from one experiment representative of three performed in triplicate. ${ }^{*}$ indicates statistically significant differences $(p<0.05)$ compared with the control (untreated cells).

Table 1). These results are in accordance with previous findings where $P$. noctiluca venom induced cell mortality on Vero and HCT 116 cell lines [26-28].

After fractionation of $P$. noctiluca venom and screening of pooled fractions for cytotoxic activity, we observed that F1 and F3 caused a market decrease of cell viability in a concentration dependent manner. IC50 values determined after $24 \mathrm{~h}$ of cell treatments are $125 \mu \mathrm{g} / \mathrm{ml}$ and $179 \mu \mathrm{g} / \mathrm{ml}$ for F1 and F3, respectively (Table 1). Whereas, F4 and F2 had no cytotoxic effect on U87 cells (Figure 2).

As shown in Figure 3, the treatment of the crude venom extract, F1 and F3 changed the cell morphology of U87 cells from flattened glioblastoma membranous morphology, representing activation state, to slender shape, representing quiescent state (Figure $3(*)$ ). Based on morphological change, we suppose that the U87 cell mortality induced by $P$. noctiluca venom extracts may be achieved by induction of apoptosis but not due to direct toxic effect. To date, $P$. noctiluca venom has been described to have a moderate cytotoxic effects on cancer cell lines and was able to promote apoptotic cell death on Vero cells [28].

One of the most frequent parameters assessed in cancer drug discovery is the impact of a given molecule on the proliferation of a cancer cell [29]. For this reason the effect of the crude venom extract and its fractions on U87 cell proliferation were assessed using MTT assay over a concentration of $10 \mu \mathrm{g} / \mathrm{ml}$ (This concentration is about 17 times less cytotoxic than IC50) after 48, 72, 96 and 120 hours.

Our results has been shown a time-dependent increase of the percentage of growth inhibition. The antiproliferative activity rates of $P$. noctiluca venom, F1, F2,
F3 and F4 were about $60 \%, 80 \%, 50 \%, 20 \%$ and 5\% respectively after 5 days of exposure (Figure 4). Among these results, crude venom, F1 and F2 appear to be the most interesting fractions and exhibit an antiproliferative effect comparable to that of the drug used clinically for tumor treatment, cisplatinum $(5 \mu \mathrm{M})$.

Similar to our results, Balamurugan et al. [30] reported the antitumor activity of Chrysaora quinquecirrha venom. Data revealed that a peptide with a molecular weight of $9 \mathrm{kDa}$, isolated from Chrysaora quinquecirrha venom by sephadex G-100 column chromatography could induce apoptosis in HEp2 and HeLa cells [30]. This peptide was further studied in vivo for its anti cancer activity. Balamurugan et al. reported that nematocyst venom of Chrysaora quinquecirrha peptide possessed significant antitumor activity comparable to that of the result obtained from the animals treated with the standard drug 5-fluorouracil [31].

Another study demonstrated that a potent cytolytic proteins and an inhibitor of papain-like cysteine proteinases (equistatin), were isolated from the sea anemone Actinia equina [32]. Equistatin has been shown to be a potent inhibitor of papain and an inhibitor of the aspartic proteinase cathepsin D [33]. Papain-like cysteine proteases have been implicated in various diseases of the central nervous system, such as brain tumors [34].

In addition to cell growth, treatment with $P$. noctiluca extracts affected another hallmark of gliomas, i.e. adhesion. According to our knowledge, such inhibitory activities of jellyfish venom on cell adhesion have not been reported yet.

Cancer cells interact with their surrounding cells and matrix proteins in order to replicate, gain nourishment, and migrate to a new location. The interaction of cancer cells with ECM is essential for metastasis, which is the principal cause of death in cancer patients. Cancer cell movement is controlled by various factors produced by cancer cells and host cells, including growth and motility factors, cytokines, cell adhesion molecules and ECM proteins. Cell adhesion molecules play a crucial role in cell motility through cell-cell and cell-ECM interactions [35]. The most-characterized cell adhesion receptors are the integrins. Integrins are cell adhesion molecules composed by the noncovalent association of $\alpha$ and $\beta$ subunits. Thus, It has notably been shown that several snake venom-derived peptides can affect integrin function. Among these peptides, disintegrins have been widely characterised and are now studied for potential use in medicine [36].

Our findings clearly show that $P$. noctiluca venom inhibited U87 cell adhesion to fibrinogen and had an IC50 of $25 \mu \mathrm{g} / \mathrm{ml}$. F1, F2 and F3 inhibited cell adhesion to fibrinogen in a dose dependent manner with an IC50 of 5,64 and $100 \mu \mathrm{g} / \mathrm{ml}$ respectively (Table 1). The 
inhibition of $\mathrm{F} 1$ at $50 \mu \mathrm{g} / \mathrm{ml}$ was 12,5 times more effective when compared to the crude venom extract at the same concentration. F4 was not able to inhibit cell adhesion to fibrinogen. Moreover, no effect could be observed on the integrin independent substratum, polyL-lysine, suggesting that the effect of $P$. noctiluca extracts indeed involved the integrin family of adhesion receptors (Figure 5). Thus, we hypothesized that crude venom, F1, F2 and F3 could affect the function of this family of adhesion receptors.

Preclinical data indicate that integrins play a key role in cancer initiation and progression [37]. They are primarily responsible for cell adhesion to ECM, and they are thus involved in anchorage-dependent cell proliferation $[38,39]$. The integrins alpha $\mathrm{V}$ beta 3 and alpha $\mathrm{V}$ beta 5 , among others, are expressed not only on the tumor vasculature and angiogenic endothelial cells, but also on tumor cells, including gliomas (reviewed in [40]). In glioblastoma, overexpression of alpha $\mathrm{V}$ beta 3 integrin is well documented [41]. Importantly, immunohistochemistry analysis revealed that alpha $\mathrm{V}$ beta 3 integrin expression was mainly confined to the tumor region and was absent in normal tissue [42].

Given the role of integrins in promoting glioma growth, invasion and angiogenesis, integrin inhibitors might be ideal therapeutic tools. Numerous antiangiogenic components targeting integrin receptors have been isolated from snake venom [43]. These proteins belong to two families, disintegrins and C-type lectin proteins. Since their initial characterization, snake venom disintegrins have been extensively studied [44]. They are potent and specific antagonists of several integrins, such as alpha $V$ beta 3 and alpha 5 beta 1 , the disintegrin family was the first to be characterized and the most extensively studied [45]. EMS16, a C-type lectin protein from Echis multisquamatus was the first example of a different class of venom proteins showing an antagonistic effect on integrins [46]. In addition, BJcuL, from the snake Bothrops jararacussu inhibits tumour and endothelial cell growth [47] and Rhodocetin from Vipera lebetina venom antagonises tumour invasion [4].

\section{Conclusions}

In conclusion, we isolated four fractions with sephadex G-75 chromatography from venom of the Mediterranean jellyfish $P$. noctiluca and evaluated their antiproliferative activity separately using U87 cells. Among the four fractions F1 and F2 and F 3 showed significant antiproliferative activity in time-dependent manner. Our results also suggest that these fractions and the crude venom are able to inhibit cell adhesion to fibrinogen in dosedependent manner. This inhibition is probably reliant on its ability to interact with integrins. Although the specific integrins affected by $P$. noctiluca venom and its active fractions have not been identified in this study, the integrin alpha $\mathrm{V}$ beta 3 and alpha 5 beta 1 might be involved. The purification and the determination of chemical structures of compounds of these active fractions are under investigation. Overall, $P$. noctiluca venom may has the potential to serve as a template for future anticancer-drug development. Further analyses are warranted and necessary to substantiate our findings.

\section{Abbreviations}

P. noctiluca: Pelagia noctiluca; MTT: 3-(4, 5- dimethyl thiazol -2-yl) 2, 5diphenyl 3-(4,5-dimethylthiazol-2-yl)-2,5-dimethyltetrazolium bromide; IC50: The concentration inducing $50 \%$ loss of cell viability; IC10: The concentration inducing 10\% loss of cell viability; ECM: Extracellular matrices; Fg: Fibrinogen; poly-L: Poly-L-lysine.

\section{Competing interests}

The authors declare that they have no competing interests

\section{Acknowledgement}

This research was supported by the Ministère Tunisien de l'Enseignement Supérieur et de la Recherche Scientifique (Laboratoire de Recherche sur les Substances Biologiquement Compatibles: LRSBC).

\section{Author details}

${ }^{1}$ Laboratory for Research on Biologically Compatible Compounds, Faculty of Dentistry, Rue Avicenne, Monastir 5019, Tunisia. ${ }^{2}$ Laboratoire des Venins et Toxines, Institut Pasteur de Tunis, 13 Place Pasteur, BP.74, 1002, Tunis Belvédère, Tunisia. ${ }^{3}$ University of Jendouba, Cité AlFaeiz rue Jamil Boutheina, Jendouba 8100, Tunisia. ${ }^{4} \mathrm{Head}$ of the Laboratory for Research on Biologically Compatible Compounds (LRSBC), Faculty of Dentistry, Monastir university, Rue Avicenne, Monastir 5019, Tunisia.

\section{Authors' contributions}

YA carried out cell cultures, cell proliferation assays and drafted the manuscript. MB carried out cell viability assays and cell adhesion assays. HBM participated to cell cultures and cell adhesion assays. MM performed statistical analysis. NM participated in the design of the study. HB contributed in correcting the manuscript and approved its final version. All authors read and approved the final manuscript.

Received: 22 March 2012 Accepted: 28 June 2012

Published: 28 June 2012

\section{References}

1. Maher EA, Furnari FB, Bachoo RM, Rowitch DH, Louis DN, Cavenee WK, DePinho RA: Malignant glioma: genetics and biology of a grave matter. Genes Dev 2001, 15:1311-1333.

2. Wong $M L$, Kaye $A H$, Hovens $C M$ : Targeting malignant glioma survival signalling to improve clinical outcomes. J Clin Neurosci 2007, 14:301-308.

3. Sarray S, Delamarre E, Marvaldi J, El Ayeb M, Marrakchi N, Luis J: Lebectin and lebecetin, two C-type lectins from snake venom, inhibit $\alpha 5 \beta 1$ and av-containing integrins. Matrix Biol 2007, 26:306-313.

4. Eble JA, Tuckwell DS: The alpha 2 beta 1 integrin inhibitor rhodocetin binds tothe A-domain of the integrin alpha 2 subunit proximal to the collagen-binding site. Biochem J 2003, 376:77-85.

5. Newman DJ, Cragg GM: Marine natural products and related compounds in clinical and advanced preclinical trials. J Nat Prod 2004, 67:1216-1238.

6. Kijjoa A, Sawangwong P: Drugs and cosmetics from the sea. Mar Drugs 2004, 2:73-82

7. Jha RK, Zi-rong X: Biomedical compounds from marine organisms. Mar Drugs 2004, 2:123-146

8. Kuramoto $M$, Arimoto $H$, Uemura D: Bioactive alkaloids from the sea: a review. Mar Drugs 2004, 1:39-54.

9. Piggott AM, Karuso P: Quality not quantity: the role of marine natural products in drug discovery and reverse chemical proteomics. Mar Drugs 2005, 3:36-63.

10. Newman DJ: Natural products as leads to potential drugs: an old process or the new hope for drug discovery? J Med Chem 2008, 51:2589-2599. 
11. Ismail H, Lemriss S, Ben Aoun Z, Mhadhebi L, Dellai A, Kacem Y, Boiron P, Bouraoui A: Antifungal activity of aqueous and methanolic extracts from the Mediterranean sea cucumber, Holoturia polii. J Med Mycol 2008, 18:23-26.

12. Rocha J, Peixe L, Gomes NC, Calado R: Cnidarians as a source of new marine bioactive compounds-an overview of the last decade and future steps for bioprospecting. Mar Drugs 2011, 9(10):1860-1886.

13. Forskal: Medusae. In Descriptiones Animalium, avium, amphibiorum, piscium, insectorum, vermium, Volume 1. Hauniae: Postmortem auctoris edidit Carsten Niebuhr; 1775:106-111.

14. Licandro P, Conway DVP, Daly Yahia MN, de Puelles ML Fernandez, Gasparini S, Hecq JH, Tranter P, Kirby RR: A blooming jellyfish in the northeast Atlantic and Mediterranean. Biol Lett 2010, 6:688-691.

15. Malej A, Malej Jr: Invasion of the jellyfish Pelagia noctiluca in the northern Adriatic: a non-success story. In Aquatic Invasions in the Black, Caspian and Mediterranean Seas, Volume Chapter 16. Edited by Dumont H, Shiganova T, Niermann U. Dordrecht, The Netherlands: Kluwer Academic Publishers; 2004:273-285

16. Mariottini GL, Giacco E, Pane L: The mauve stinger Pelagia noctiluca (Forsskål, 1775). Distribution, ecology, toxicity and epidemiology of stings. A review. Mar Drugs 2008, 6(3):496-513.

17. Doyle TK, De Haas H, Cotton D, Dorschel B, Cummins V, Houghton JDR, Davenport J, Hays GC: Widespread occurrence of the jellyfish Pelagia noctiluca in Irish coastal and shelf waters. J Plankton Res 2008, 30:963-968.

18. Theoharides TC: Mast cell secretion: basis for jellyfish poisoning and prospects for relief. In Workshop on Jellyfish Blooms in the Mediterranean Athens, Greece:: 31 October-4 November 1983:63-73.

19. Maretic Z, Matic-Piantanida D, Ladavac J: The bloom of the jellyfish Pelagia noctiluca in the Mediterranean and Adriatic and its impact on human health. In Jellyfish blooms in the Mediterranean, Proceedings of the II Workshop on Jellyfish in the Mediterranean Sea. MAP Technical Reports Series, No. 47. Athens: UNEP; 1991:260-267.

20. Arillo A, Burlando B, Carli A, Mariottini GL: Mitochondrial alteration caused by cnidarians toxins: a preliminary study. Boll Soc It Bio/ Sper 1994 70:307-313

21. Marino A, Morabito R, Pizzata T, La Spada G: Effect of various factors on Pelagia noctiluca (Cnidaria, Scyphozoa) crude venom-induced haemolysis. Comp Biochem Physiol A 2008, 151:144-149.

22. Bradford MM: A rapid and sensitive method for the quantification of microgram quantities of protein utilizing the principle of protein-dye binding. Anal Biochem 1976, 72:248-254.

23. Bazaa A, Luis J, Srairi-Abid N, Kallech-Ziri O, Kessentini-Zouari R, Defilles C, Lissitzky JC, El Ayeb M, Marrakchi N: MVL-PLA2, a phospholipase A2 from Macrovipera lebetina transmediterranea venom, inhibits tumor cells adhesion and migration. Matrix Biol 2009, 28:188-193.

24. Mossmann T: Rapid calorimetric assay for cellular growth and survival: application to proliferation and cytotoxicity assays. J Immunol Met 1983, 65:55-63.

25. Mariottini GL, Pane L: Mediterranean jellyfish venoms: a review on Scyphomedusae. Mar Drugs 2010, 8:1122-1152.

26. Ayed Y, Boussabbeh M, Zakhama W, Bouaziz C, Abid S, Bacha H: Induction of cytotoxicity of Pelagia noctiluca venom causes reactive oxygen species generation, lipid peroxydation induction and DNA damage in human colon cancer cells. Lipids Health Dis 2011, 9:10-232.

27. Eisenbrand G, Pool-Zobel B, Baker V, Balls M, Blaauboer BJ, Boobis A, Carere A, Kevekordes S, Lhuguenot JC, Pieters R, Kleiner J: Methods of in vitro toxicology. Food Chem Toxicol 2002, 40(2-3):193-236. Review.

28. Ayed Y, Chayma B, Hayla A, Abid S, Bacha H: Is cell death induced by nematocysts extract of medusa Pelagia noctiluca related to oxidative stress? Environ Toxicol 2011, 10.1002/tox.20740.

29. Griffiths $M$, Sundaram H: Drug design and testing: profiling of antiproliferative agents for cancer therapy using a cell-based methyl[3H]-thymidine incorporation assay. Methods Mol Biol 2011, 731:451-465.

30. Balamurugan E, Kumar DR, Menon VP: Proapoptotic effect of Chrysaora quinquecirrha ( Sea Nettle ) nematocyst venom peptide in HEp 2 and HeLa cells. Eur J Sci Res 2009, 35:355-367.

31. Balamurugan E, Reddy BV, Menon VP: Antitumor and antioxidant role of Chrysaora quinquecirrha (sea nettle) nematocyst venom peptide against ehrlich ascites carcinoma in Swiss Albino mice. Mol Cell Biochem 2010, 338:69-76.
32. Lenarcic B, Ritonja A, Strukelj B, Turk B, Turk V: Equistatin, a new inhibitor of cysteine proteinases from Actinia equina, is structurally related to thyroglobulin type-1 domain. J Biol Chem 1997, 272:13899-13903.

33. Lenarcic B, Turk V: Thyroglobulin Type-1 domains in equistatin inhibit both Papain-like cysteine proteinases and Cathepsin D. J Biol Chem 1999, 274:563-566.

34. Brömme D, Petanceska S: Papain-Like Cysteine Proteases and Thei Implications in Neurodegenerative Diseases. In Role of Proteases in the Pathophysiology of Neurodegenerative Diseases. Edited by Lajtha A, Banik NL. New York, NY, USA: Springer; 2002:47-61.

35. Tsuji T, Kawada Y, Kai-Murozono M, Komatsu S, Han SA, Takeuchi K, Mizushima H, Miyazaki K, Irimura T: Regulation of melanoma cell migration and invasion by laminin-5 and a3b1 integrin (VLA-3). Clin Exp Metastasis 2002, 19:127-134.

36. McLane MA, Sanchez EE, Wong A, Paquette-Straub C, Perez JC: Disintegrins. Curr Drug Targets Cardiovasc Haematol Disord 2004, 4:327-355.

37. Desgrosellier JS, Cheresh DA: Integrins in cancer: biological implications and therapeutic opportunities. Nat Rev 2010, 10:9-22.

38. Braud $\mathrm{S}$, Bon $\mathrm{C}$, Wisner $\mathrm{A}$ : Snake venom proteins acting on hemostasis. Biochimie 2000, 82:851-859.

39. Cruet-Hennequart S, Maubant S, Luis J, Gauduchon P, Staedel C, Dedhar S: av integrins regulate cell proliferation through integrin-linked kinase (ILK) in ovarian cancer cells. Oncogene 2003, 22:1688-1702.

40. Ruegg C, Mariotti A: Vascular integrins: pleiotropic adhesion and signaling molecules in vascular homeostasis and angiogenesis. Cell $\mathrm{Mol}$ Life Sci 2003, 60:1135-1157.

41. Schnell O, Krebs B, Carlsen J, Miederer I, Goetz C, Goldbrunner RH, Wester HJ, Haubner R, Pöpperl G, Holtmannspötter M, Kretzschmar HA, Kessler H, Tonn JC, Schwaiger M, Beer AJ: Imaging of integrin alpha (v) beta (3) expression in patients with malignant glioma by [18F] Galacto-RGD positron emission tomography. Neuro Oncol 2009, 11(6):861-870

42. Beer AJ, Haubner R, Sarbia M, Goebel M, Luderschmidt S, Grosu AL, Schnel $\mathrm{O}$, Niemeyer M, Kessler H, Wester HJ, Weber WA, Schwaiger M: Positron emission tomography using [18F] Galacto-RGD identifies the level of integrin alpha (v) beta 3 expression in man. Clin Cancer Res 2006, 12:3942-3949.

43. Avraamides CJ, Garmy-Susini B, Varner JA: Integrins in angiogenesis and lymphangiogenesis. Nat Rev Cancer 2008, 8:604-617.

44. Kallech-Ziri O, Luis J, El Ayeb M, Marrakchi N: Snake venom disintegrins: classification and therapeutic potential. Arch Inst Pasteur Tunis 2007, 84:29-37. Review.

45. McLane MA, Joerger T, Mahmoud A: Disintegrins in health and disease. Front Biosci 2008, 13:6617-6637

46. Marcinkiewicz C, Lobb RR, Marcinkiewicz MM, Daniel JL, Smith JB, Dangelmaier C, Weinreb PH, Beacham DA, Niewiarowski S: Isolation and characterization of EMS16, a C-lectin type protein from Echis multisquamatus venom, a potent and selective inhibitor of the a2b1 integrin. Biochemistry 2000, 39:9859-9867.

47. de Carvalho DD, Schmitmeier S, Novello JC, Markland FS: Effect of BJcuL (a lectin from the venom of the snake Bothrops jararacussu) on adhesion and growth of tumor and endothelial cells. Toxicon 2001, 39:1471-1476.

\section{doi:10.1186/1476-511X-11-84}

Cite this article as: Ayed et al:: Impairment of the cell-to-matrix adhesion and cytotoxicity induced by the Mediterranean jellyfish Pelagia noctiluca venom and its fractions in cultured glioblastoma cells. Lipids in Health and Disease 2012 11:84. 